bottle has often been felt. With this idea in mind Dr. H. M. Hill designed a pipette and bottle which admirably answers the purpose and has been found to be a great help in weighing milk for analysis. In laboratories where only analytical work is done or where each assistant or student has his own apparatus it would not be necessary to change the form of the apparatus as originally designed; but in large technical laboratories where a great variety of analytical, as well as commercial, work is being done, $I$ found it necessary to make certain changes in this apparatus on account of the small ground cap, which is fitted over the mouth-piece of the two-bulbed pipette in the original form of the apparatus, being continually mislaid and very often lost. Sometimes the chemist using two or more pipettes will misplace

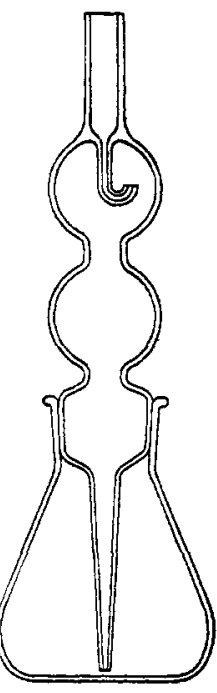
the cap, thereby causing an error in the weighing, and the work must be begun anew. The improved apparatus obviates all these disadvantages and errors, and consists, as is seen in the drawing, of a weighing-bottle $1 \frac{3}{4}$ inches in diameter in its widest part, $2 \frac{1}{2}$ inches high and $\frac{3}{4}$ inch in diameter of mouth, into which is fitted a pipette $5 \frac{1}{2}$ inches long, with three bulbs. The lower bulb acting as a stopper and the upper one having a small bent capillary tube inserted between mouth-piece and bulb, prevents evaporation. The pipette weighing-bottle weighs from 25 to 27 grams and has been found to be of excellent service in the analysis of oils and light liquids. For use in weighing heavy liquids, such as bark extracts and the like, the lip of this pipette and capillary tube must be of larger diameter.

LOUIS E. LEVI.

CHEMICAL DEPARTMENT,

PFISTER AND VOGEL LEA CO.

MilwaUkeE, Wis.

\title{
REVIEW OF PHYSICAL CHEMISTRY.
}

BY F, G. COTTRELL.

Received February 20, 1905.

THE following article merely attempts to supplement the regular reviews of American Chemical Research, in this Journal, by citing the more important foreign work for the past year or more which falls within the somewhat loosely defined 
field of physical chemistry. The mere investigation and description of individual substances and systems from the physico-chemical standpoint has become so general in the last few years that in such reviews as the present its treatment must for the most part be left to the inorganic or organic workers concerned with this or that particular class of bodies. In fact it may be fairly said that as fast as what we to-day term physical chemistry is reduced to definite laws, it ceases to directly concern the physical chemist proper and becomes the tool and method of the specialist in other fields.

The past decade and more has been marked by the development and wide-spread application of (a) the laws governing heterogeneous equilibrium (phase rule work as it is often called), (b) the electrolytic dissociatiou theory in the case of dilute aqueous solutions, and $(c)$ the quantitative treatment of reaction velocities and homogeneous equilibrium. To-day electrolytic theories are taking on a new interest as investigation leaves the beaten path of dilute solutions turning to those of higher concentration, to non-aqueous solvents and even to solids and gases. As to reaction velocities it may fairly be said that except for the extension of the already established laws and methods to other fields, notably biology, we have for the past few years been practically at a standstill waiting for a clear conception of what may be termed chemical resistance or at least a method of directly expressing what it is that prevents chemical systems from coming immediately to true equilibrium. The Ohm's Law of chemistry still seems as far off as ever. Just as the broad thermodynamical considerations of Gibbs, Helmholtz, van't Hoff and others lead us to lay aside in many cases, as immaterial, distinctions between physical and chemical agencies and substitute for them the objective conceptions of "homogeneous" and "heterogeneous," so now in connection with the critical state and the colloids we are meeting with transitional phenomena which in turn seem often to evade classification and treatment under these very laws. It is interesting to note that these very limitations were clearly pointed out and discussed by Gibbs in his original memoirs in the seventies and in his treatment of surface phenomena, in the reviewer's opinion, will yet be found the key to the subject of colloids.

Passing to the individual contributions and beginning with those relating to the critical state we find quite an activity in the subject.

I. Traube and G. Teichner (Ann. Phys. (4), I 3, 595-619, I904; $Z$. anorg. Chem., 38, 399-407, I904) have busied themselves with the critical phenomena of pure liquids. They find the critical temperature of water (working in quartz tubes) to be $374^{\circ}$, as against $359^{\circ}-364^{\circ}$ of older observers. They also examined mercury up to $1000^{\circ} \mathrm{C}$. without reaching its critical point. This lat- 
ter confirms the observation of Strutt of a year or more ago. H. Happel (Ann. Phys. (4), 13, 340-36I, I904), assuming parallelism of mercury and argon, has computed the critical temperature of mercury as $1370^{\circ}$ absolute with a critical pressure of $456 \mathrm{~atm}$. His paper also contains some interesting comments on the classes into which substances fall when viewed in the light of equations for corresponding states. The most interesting of the work of Traube and Teichner is, however, the experiment, carried out by the latter, of enclosing a number of glass spheres of different mean specific gravity in sealed tubes of carbon tetrachloride. At $\mathrm{I}^{\circ}$ above the critical temperature nearly 50 per cent. difference in specific gravity was found in different portions of the tube, the spheres distributing themselves from top to bottom; and at $6^{\circ}$ above critical temperature 8 per cent. difference still remained.

Traube seeks for an explanation in a real difference between liquid and gaseous molecules ("Gasonen" and "Fluidonen"). In support of this he finds $b$ of van der Waals' equation to differ for the gaseous and liquid states with "normal" liquids. His point of view here suggests strongly the recent work of $\mathrm{T}$. W. Richards on compressibility of atoms (Proc. Am. Acad. Arts and Science, 37, 3-I 7 and 399-4I I ; 38, 293-3 I 7 ; Abstract, this Journal, 23, R. I59 and 24, R. 44I).

Another very suggestive treatment of the same subject is given by G. Baker (Ztschr. phys. Chem., 49, 609-617, 1904). The paper is the extension of a previous one on the theory of capillarity (Ibid., 48, I-39, I904), and points out from a purely mathematical standpoint that the physical region of discontinuity between gas and liquid should increase in thickness as temperature rises. In the neighborhood of the critical point this increase is very rapid, approaching infinity as a limit in the critical point itself. The apparent disappearance of the meniscus is therefore not a proof that the critical point in the sense of Andrews and van der Waals has been reached, and all the phenomena observed by Teichner lie really within the capillary layer which is expressly excluded in the development of van der Waals. Another point brought out by Teichner is the sudden change at the critical temperature in the temperature-"total heat," (i. e., latent heat + specific heat) curve for a system of constant volume.

During the past year the critical point of two component systems has received much attention. Centnerszwer and Teletow ( $Z$ tschr. Elektroch., 9, 799-802, 1 903), working on solutions in sulphur dioxide, and Smits (Ibid., 9, 663), working with solutions of anthraquinone in ether, have found cases of retrograde solution analogous to the well-knowı retrograde condensation; i. e., as the temperature rises a homogeneous solution may deposit solid and at a higher temperature this solid passes back again into the fluid phase. Van der Waals has treated the matter in a 
purely theoretical paper (Versl. Kon. Ak. Amsterdam, Oct. 3 I and Nov, 28, 1903, 12, 439-443 and 606-615; English translation, 6, 230-244 and 357-366). In a second paper Centnerszwer (Ztschr. phys. Chem., 46, 427-502, 1903) shows that the critical temperature of the solvent is depressed by non-volatile solutes, according to the same law as the ordinary boilingpoint, and gives the constants for several liquids. The dielectic constants and electrical conductivity of pure liquids and of solutions passing through their critical point have been investigated by Eversheim (Ann. Phys. (4), 13, 492-5II, I904). He found a rapid decrease but no discontinuity. Kraus (Phys. Rev., 18, 40-56 and 89-103, 1904) found for alcohol solutions of alkaline haloids a studden change in temperature co-efficient at the critical point when the tube was just full at this temperature. Van der Waals (Versl. Kon. Ak. Amsterdam, I2, 82-I10, 1903; English translation, 6, I23-15I ; Abstract, see Phys. chem. Cen$\operatorname{tr} b l ., 1,23 \mathrm{I})$ has given us a review of the various attempts to improve on the original van der Waals equation. He now inclines to consider " $a$ " as a constant and to work out " $b$ " as a function of temperature and particularly of volume (Cf. T. W. Richards above). He thinks little of Traube's assumed difference between liquid and gaseous molecules.

In the matter of systems with two liquid layers and the point of total miscibility, Kuenen (Phil. Mag. (6), 6, 637-53, I903) has reviewed the field, especially as regards combined effects of pressure and temperature.

The liquid crystals of Lehmann, another border line phenomenon, are still a matter for dispute. Rotarski (Phys. chem. Centrbl., $I, 8)$ claims to have shifted the inversion point of $p$-azoxyanisol by further purification and considers it a mixture of the azoand azoxy compound. Coehn (Ztschr. Elektroch., 10, 857), and Bredig and Schukowsky (Ber. chem. Ges., 37, 3419, I904) tried electrical endosmose experiments upon them without success, also high centrifugal force with negative results. Tammann, in his book on crystallization and fusion, takes the stand that we have all grades of hardness in crystals from the diamond to the softest of the fatty acids and there is no reason why we should not go a step further and have crystals so soft as to be deformed into drops by their own surface tension. He therefore stands strongly for the name "liquid crystals" rather than "crystalline liquids."

F. G. Beilby, in a series of articles on the surface structure of solids $(J$. Soc. Chem. Ind., 22, I 66-1 I77; Nature, 70, 31; Proc. Roy: Soc., 72, I8-232 ; Electrochemist, 3, 806-819), brings forward strong evidence through electromotive force measurements, optical transparency and direct microscopic methods for the view that in the polishing of metals and even such substances as iceland spar, the surface undergoes a species of flow and becomes modified to an extent justifying us in considering it as an 
allotropic form with reference to the main body of the material. The work of Spring ( $J$. Chim. Phys., I, 593, I904) on the production of allotropic forms by great pressure also tends to bear out these conclusions.

Under the head of molecular weight determinations we meet some new and interesting solvents. Beckmann used bromine for boiling-point determinations of $\mathrm{Al}_{2} \mathrm{Br}_{6}$, the double formula being sustained (Ztschr. phys. Chem., 46, 853-866). In the same article is a caution against methylene iodide as a solvent, as it crystallizes in two modifications whose melting-points only differ by $0.47^{\circ}$. Schenk and Buck (Ber. chem. Ges., 37, 915-917) have used phosphorus as a solvent for solid phosphine and obtain $\mathrm{P}_{12} \mathrm{H}_{0}$ as its formula. Bottomley ( $J$. Chem. Soc., 83, I42 I-I425) has used surface energy methods on fused salts and gives as association factors $\mathrm{NaNO}_{3}=10.68, \mathrm{KNO}_{3}=8.73$. Spercinski ( $Z$ tschr . phys. Chem., 46, 70-78), working with a new and delicate form of differential tensimeter, confirms by direct vapor pressure measurements Kuster's results on molecular weight of $\beta$-naphthol and napthaline in solid solution. Abegg and Labendzinski (Ztschr. Elektroch., ro, 77-78) give a convenient collection of data on complex building in metallic salt solutions, together with some new data. Bruni and Manuelli (Ztschr. Elektroch., 10, 60I-604), also Lobry de Bruyn (Akad. Amsterdam, June 27, I903, p. 91), have worked with hydrated and anhydrous chlorides of $\mathrm{Mn}, \mathrm{Co}, \mathrm{Ni}, \mathrm{Cu}$ and other salts in urethane, as solvent with no dissociating power, and in acetamide, as solvent with high dissociating power. In urethane salts they gave normal values, many holding all or part of their water of crystallization. In acetamide they all showed strong dissociation.

Much of the work on electrolytes in non-aqueous solvents has already been referred to in this Journal $(27,65)$. In addition may be mentioned the very complete work of Walden (Ztschr. phys. Chem., 46, I03-188, I903), consisting of quantitative measurement of conductivity and dielectric constant of fourteen classes of organic solvents, all specimens being purified with great care. All the solvents used, when sufficiently pure, gave surprisingly similar values for their own conductivity. $\kappa_{25}=$ from I to $5 \times \mathrm{IO}^{-7}$, with some four or five exceptions, where the values were about one hundred times greater. The highest conductivities are generally found in $\mathrm{OH}$ and $\mathrm{CO}$ compounds. A thorough review of earlier work is given and another paper promised. Mittasch (Ztschr. phys. Chem., 46, 37-42, I903) finds $\mathrm{Ni}(\mathrm{CO})_{4}$ to be a very poor electrolytic solvent. Its dielectric constant is 2.2 and its molecular weight is normal. Joh. Schroeder (Habilit. Schrift. Giessen, 1904, p. 58; Phys. chem. Centrbl., I, 59 I) has studied the reactions and molecular weights of $\mathrm{Ag}, \mathrm{Hg}, \mathrm{Cu}$ and $\mathrm{Fe}$ halides in pyridine. A general summary and extensive bibliography of 
the subject up to September, 1903, is given by P. Dutoit $(J$. Chim. Phys., I, 617-656, I904).

The question of the absolute potential of a single electrode has been taken up again of late by Billitzer (Wien Akad Ber., I12, I 553-I 595; also Ztschr. phys. Chem., 48, 513-548). He used at first the mercury dropping electrode, but in a somewhat different manner from previous observers. Its potential was maintained from without at various values and by direct chemical analysis the point was determined at which mercury was neither given to or taken from the solution. The neutral point for the particular arrangement used was thus located between -0.37 and $-0.43\left(\mathrm{H}\right.$ in $\frac{\mathrm{N}}{\mathrm{I}} \mathrm{H}_{2} \mathrm{SO}_{4}=0$ ), agreeing well with -0.4 , as given by the previous work on electrical endosmosis (Wurtzburg meeting of Bunsen Gesellschaft). A second method depended upon setting up currents by suddenly extending or contracting a mercury surface in the electrolyte. The current changes sign twice, viz., at +0.35 and -0.4 volt. Between two mercury electrodes in the same solution a current flows if the electrolyte, over one electrode, is kept in motion. This current reverses its direction when the electrodes are brought to a potential of -0.4 volt, but not at +0.35 volt, from which the author concludes that the latter point is due to changes in surface tension due to stretching and contracting the surface. He urges the point -0.4 volt as the true absolute neutral. Wulf (Ztschr. phys. Chem., 48, 87-96) has confirmed the Helmholtz formula for gas electrodes between $\mathrm{r}$ and $\mathrm{I}, \mathrm{OoO}$ atmospheres. Muthmann and Fraunberger (Sitzber. bayr. Akad., 34, 20I-24I, 1904; Phys. chem. Centrbl., I, 695) investigated the cause of the passive state of iron and other metals and attribute it to a film of oxide. Even very short contact with the air produces some effect. They claim that generally accepted single potentials for iron and some other metals are vitiated by this and redetermine the same under special precautions. Hollis (Proc. Cambridge Phil. Soc., 12, 253 and 462-465, 1904) shows that passive state can only be produced below a certain temperature for each metal, $\mathrm{Fe}$ a little below $100^{\circ} \mathrm{C}$., $\mathrm{Ni}$ about $72^{\circ} \mathrm{C}$., and $\mathrm{Co}$ about $10^{\circ} \mathrm{C}$. A general review of the whole subject and discussion of the theories advanced is given by Sackur (Chem. Ztg., 28, 954$956,1904)$.

The possibility of making a sharp analytical separation even on a mercury cathode is proved by Coehn and Kettembeil (Ztschr. anorg. Chem., 38, I98-23 I) for the alkaline earths. Strontium required 0.2 volt more than barium, and calcium 0.25 more than strontium to deposit it. Wedekind (Chem. Ztg., 28, 268-270) applies this same principle to separate radium from barium, but does not seem to consider it a practical method (see also Marckwald, Ber. 
chem.Ges., 37, 88-91). Siemens (Ztschr. anorg. Chem., 4I, 249-275) has investigated to what extent $\mathrm{Na}, \mathrm{K}, \mathrm{NH}_{4}, \mathrm{Li}, \mathrm{Be}$ and $\mathrm{Al}$ may be made to alloy with $\mathrm{Ni}, \mathrm{Co}, \mathrm{Fe}, \mathrm{Zn}, \mathrm{Cd}, \mathrm{Sn}, \mathrm{Cu}$ and $\mathrm{Ag}$. Positive results were only obtained in the case of $\mathrm{Mg}$ with $\mathrm{Ni}, \mathrm{Fe}$, Co and $\mathrm{Zn}$, the alkalies with $\mathrm{Ni}$ and $\mathrm{Sn}$ and possibly $\mathrm{NH}_{4}$ with $\mathrm{Ag}$. As much as 3 per cent. $\mathrm{Mg}$ may come down with $\mathrm{Ni}$, a fact which is made use of in securing specially coherent deposits in Ni plating. Numerous attempts have been made to apply alternating currents to electrolytic processes. Blochet and Petit (Compt. rend. 128, 419-42 I and 1095-1097) reached 50 per cent. current efficiency for the solution of $\mathrm{Pb}$ in $\mathrm{H}_{2} \mathrm{SO}_{4}$ and also succeeded well with $\mathrm{Pb}, \mathrm{Co}$ and $\mathrm{Fe}$ in $\mathrm{KCN}$. In $\mathrm{KCN}$ solution with $20-80$ amp. per square decimeter $0.4-0.6$ gram per hour was dissolved. Pierce and Couchet (Compt. rend., $138,36 \mathrm{r}-363)$ have applied alternating currents to reduction of nitrates, chromates and nitrobenzene with technical ends in mind. The best systematic treatment that has appeared is by Le Blanc and Schick (Ztschr.phys. Chem., 46, 21 3-243, 1903). They studied chiefly the effect of varying frequency, current density and concentration. Incidentally they arrived at an estimate of the velocity of formation of complex ions. With $\frac{\mathrm{N}}{10} \mathrm{Cu}^{\prime \prime}$ and $\frac{\mathrm{N}}{\mathrm{I}} \mathrm{CN}$ combination was practically complete in 0.001 minute while with $\frac{\mathrm{N}}{800} \mathrm{Cu}^{\prime \prime}$ at end of $\frac{\mathrm{I}}{80000}$ minute practically no combination had occurred. Schlomilch (E.lektrotechn. Ztg., 24, 959, 1903) describes an electrolytic coherer. Its essential feature is an anode consisting of a fine platinum or gold point in sulphuric acid. A polarizing electromotive force is applied in just sufficient amount to effect visible electrolysis. When the point is subjected to electrical waves the residual current greatly increases only to fall back again when the electric waves are cut off. Rothmund and Lessing (Ann. Phys. (4), 15, 193-231) have since carried out a more systematic study of the phenomenon and determined the best conditions. They find the effect both at anode and cathode and explain it on the grounds that the electric oscillation periodically increases and decreases the potential on the electrodes. When the potential due to the wave is added to that of the polarizing battery a current flows; when opposed no current flows. In other words the cell acts toward the electric waves much as the aluminum plate of the ordinary electrolytic rectifier (see Norden: Ztschr. Elektroch., 6, I 59-I67 and i 88202). Electrolytic conduction in solids has received considerable attention since the advent of the Nernst lamp but most of the work has been of a commercial type and consequently little has found its way into print. Reynolds (Dissert. Göttingen, I902; also a brief abstract in Nachrichten Göttingen Akad. d. Wiss. 
Nernst and Reynolds, I900, p. 330). In the matter of electric discharge through gases Stark and Cassuto (Phys. Zeit., 5, 264269) have tried the effect of cooling the electrodes in various ways and find that the anode may be cooled to any degree without affecting the are but that slight cooling of the cathode breaks the current. This agrees well with the theory of discharges of negative ions from the hot cathode. Monash (Dissert. Darmstadt. Hochsch. See Phys. chem. Centrbl., I, I68) has studier effect of length of arc on its potential, using an alternating current of $0.02-0.06 \mathrm{amp}$. between various metals. The superposition of disruptive discharge upon the true arc is brought out and the great effect of small impurities of carbon in the metals noted. Kerkby (Phil. Mag. (6), 7, 223-232) has studied the effect of the current from a charged zinc plate illuminated with ultraviolet light on a mixture of hydrogen and oxygen at low pressure but found no appreciable combination up to the sparking potential. The author then speculates on the mechanism of combination for these two substances.

J. J. Thomson (Phil. Mag. (6), 7, 237-265, 1904) has brought forward a rather daring attempt to explain the structure of the elements in harmony with the periodic system and the recently discovered facts of radioactivity. He pictures the atoms as built up of negative electrified corpuscles within a sphere of uniform positive electrification. Then from the principles of mechanics works out the possible stable arrangements of such a set of particles and attempts to connect these with the known properties of the various elements.

Out of the great mass of spectroscopic work may be noted as of special chemical interest the following: von Bolton ( $Z$ tschr. Elektroch., 9, 913-922, 1903) describes the spectra produced at the surface of a metallic conductor and electrolyte on the passage of a r lo-volt current of high density. A more exact and detailed account of similar phenomena with the Whenelt interrupter by Morse (Astrophys. Jr., 19, I62-186) has appeared in this country.

Nasini and Anderlini (Rend. R. Acc, di Lincei (5), 13, 59-66; cf. Phys. chem. Centrbl., I, 653) claim to have obtained emission spectra of nitrogen and iodine by simply heating the gases in an electric furnace. Magini (Phys. Zeit., 5, 145-147), also Baly and Desch (J. Chem. Soc. (London), 85, IO29-IO4I), working in the violet, and Ikli (Phys. Ztschr., 5, 27 1-277), in the infra red, have sought for a relationship between absorption bands and chemical constitution; the former with positive but the latter with negative results.

Turning to photochemistry and photography we find Liesegang (D. photo. Ztg., 28, 102-104; abstr. Phys. chem. Centrbl., I, 208) attempting to explain the great difference in the thinning of the image in the hypo-bath, observed when different developers 
are used, on the ground that the powerful developers reduce directly to metallic silver, while with the weaker ones only the sub-halide stage is reached. Lumiere and Seyewetz $(D$. photo. Ztschr., 28, I85-I88; Phys, chem. Centrbl., I, 37 I) point out that only those reducing agents are able to act as developers with sodium sulphite alone (without alkali) which have an amino group in the benzene nucleus and they lose the power if a substitution is made in the group which greatly reduces its basic nature. Kirchner (Ann. Phys. (4), 13, 239-270) has studied the structure of the film of the Lippmann color plates, particularly the refractive indices of gelatin and silver, and concludes that about one-third of the available silver is reduced and that it makes up about $1 / 300$ of the total thickness of the film. He believes the silver to be truly massive and not "molecular," as has been suggested by some. Luther and Weigert (Berlin Akad. $B e r$., 1904, pp. 828-839) have studied from the standpoint of reaction velocity the polymerization of anthracene dissolved in boiling phenetol. In the light the polymerization proceeds and in the dark the action is reversed. So few reversible photochemical reactions are known and these have been so little studied that this homogeneous system becomes of special interest. The homogeneity of the system has, however, been questioned by Nernst (see Breslau meeting of Deutsch. Naturf. u. Aertzte., Sept., 1904) on the ground that the light must vary in intensity as we proceed into the mass of the liquid. The authors find the reaction to be monomolecular and the constants in both directions were determined. For equilibrium they found the relation: conc. of dianthracene $=$ const. $\frac{\text { (Intensity of light) } \times \text { (surface exposed) }}{\text { volume }}$

It is notable that the final concentration of the dianthracene appears to be independent of the concentration of the anthracene. Further work is promised. Byk has given us a very interesting theoretical paper (Ztschr. phys. Chem., 49, 64I-687) on the photochemistry of optically active bodies and the possibility of producing active bodies by purely physical means, viz., circularly polarized light. He shows that due to the inclination of the earth's axis there is a slight predominance of circularly polarized light of the one sign over that of the reverse sign. It has been shown experimentally that optical isomerides absorb right and left circularly polarized light to different extents and photochemistry has shown that absorption and photochemical action run parallel wherever the latter exists. From this chain of laws the authors explain why we have in plant and animal substances one of the optical antipodes instead of the racemic mixture characteristic of our laboratory syntheses. The experimental part of the paper aimed at the direct production of an active body from a racemic mixture by photochemical means gave negative results. This may mean that the examples were poorly chosen or that the effects 
in a single instance are too small to be appreciable, and it is by the cumulative process, which the author points out is to be expected in nature, that the effects become appreciable. Schaum and Braun (Ztschr. wiss. Photog., 1, 377-384) have worked with plates free from gelatin and find such phenomena as solarization to exist there as well, so that their explanation is not referable to the gelatin. Röntgen rays were also active on a film of silver bromide on platinum, so the theory of fluorescence of the glass or gelatin in their case must now be discarded. In the study of the selenium cell the theory which attributes its action to traces of metallic selenides seems to be losing ground. Berndt (Phys. Ztschr., 5, 12 I-1 24) and Pfund (Phil. Mag., (6), 7, 26-39), both working with graphite electrodes, reject it. The former attributes the change of resistance to displacement of equilibrium between two crystalline modifications of the selenium itself. The latter measured the sensitiveness with various admixtures of metallic selenides and found the point of maximum sensitiveness in the spectrum to be independent of their presence or nature. Marc (Ztschr. anorg. Chem., 37, 459-474) comes to the same conclusion as Berndt, from studies of the temperature coefficient of the cells in different parts of the spectrum.

The more important data concerning radium and radioactivity have been given in the review on inorganic chemistry (this Journal, 27,63 ), and a comprehensive review would carry us beyond our limits. For such review see book list at end of this article, also W. Crooks "Modern Conceptions of Matter" (Chem. News, 87, 277-28I) in his address at Berlin Congress of Applied Chemistry; Rutherford, Bakerian lecture before the Royal Society, May I9, 1904 (Proc. Roy. Soc., 73, 493) and also a review by Curie himself (J.Chim. Phys., I, 409-449; and Phys. Ztschr., 5, 281-288; 31 33 I $8 ; 345-349)$. The theory which has fast been gaining ground that radium was constantly being formed by the disintegration of uranium and in its turn passing on to simpler bodies, among them helium, seems to have met with a set back as far as the first step is concerned, from the work of Soddy (Nature, 70, 30). He purified a kilo of uranium nitrate until it contained less than ${ }_{10}^{-13}$ grams of radium. At the end of a year not more than $\mathrm{IO}^{-1 \mathrm{I}}$ grams had accumulated (this being the limit of sensitiveness of his instruments at that time). If the radioactivity of uranium is due to its decomposition into radium, according to the above theory, we should look for about $5 \times \mathrm{IO}^{-7}$ grams to be produced in the above experiment. Giesel (Ber. chem. Ges., 36, 342, and 37, $1696-1699$ ) believes he has another radioactive element bearing the same relation to lanthanum that radium does to barium, and calls it "emanium." It acts much more strongly in the spinthariscope than radium does. Its source is also pitchblend. Ramsay and Cook (Nature, 70, 34I-342) describe the coloring of glass by radium and the extraction of an emanation 
from the glass by solution in water, and suggest it may be a case of reversal of the radioactive development, by conversion of the energy of the radiation back again into chemical energy, the glass, in fact, acting as a sort of storage cell.

Among other papers on the chemical action of radium rays may be mentioned: Pellini and Vaccari (Atti. R. Ac. Lincei (5), 13, 269-275), working with hydroiodic acid and with propyl and isopropyl iodides, got positive results and attribute the action to the $\gamma$-rays. With $\mathrm{H}+\mathrm{Cl}$ and the photometer solutions of Neiper de St. Victor and Roussin (see Eder Jahrb. d. Photo., I $89 \mathrm{I}$, pp. 370-382) they got negative results. Hardy and Willcock found a strong oxidizing action of the rays on iodoform (Proc. Roy. Soc., 72, 200-204; Ztschr. phys. Chem., 47, 343-352). They attribute the greater part of the action to $\beta$ - and some to easily penetrating $\gamma$-rays. Sunlight worked somewhat more strongly and the authors attribute the violent physiological action of radium rays to their penetrating power. Hardy (Proc. Physiol. Soc., p. 29; J. of Physiology, 29, I903) has also shown the powerful coagulating effect of the radium emanation on an alkaline solution of the globulin from ox serum. An acid solution of the same became clearer and lost its opalescence. Tenton (Proc. Camb. Phil. Soc., 12, 424-426; Phys. chem. Centrbl., 1, 425) finds $\mathrm{H}_{2} \mathrm{O}_{2}$ decomposes about twice as fast when exposed to $\mathrm{RaBr}_{2}$ as when left alone in the dark. The so-called "N-rays" first reported by Blandlot as emitted from hot bodies and later from a variety of sources, such as contracting muscles, have attracted a considerable amount of attention, but at present seem to be considered by the majority of serious workers as purely subjective phenomena (see Schenk, McKendrick and Colquhoun: Nature, 69, 486 and 534; also Lummer: Phys. Ztschr., 5, I 26-1 28).

Armstrong and Loury (Proc. Roy. Soc., 72, 258-264) note that saccharin crushed under an opaque screen of barium platinocyanide or zinc blende produces brilliant flashes of light; also menthylphenylformylacetate produces flashes of light on crushing or crystallization from light petroleum. They assume labial and stable forms and believe that a change of the one form to the other is responsible for the phenomena. Gutton (Compt. rend., 138, 268-270, 352-353, 568-569) finds the luminosity of calcium sulphide increased by being placed in a variable magnetic field. A uniform field has no effect. He claims the phenomenon is very delicate and uses it to show magnetic effect of convection currents. Hemptine (Compt. rend., 138, 754-755), however, tried it with negative results, but suggests that his sulphide may not have been sufficiently sensitive. Schmidt (Ann. Phys., (4), 13, $622-633$; see also 9,707 ) finds that if oxides of aluminum and zinc are pure they show no fluorescence in the canal rays of a discharge tube, but the least trace of foreign oxide produces fluorescence, the color depending on the kind of oxide. In light 
of these facts the work of Wein and Tafel is criticized. See also a reply by Tafel (Ann. Phys. (4), 14, 206).

The literature of colloids and colloidal solutions has received many additions of late, but as a comprehensive review of this field appeared in the October number of this Journal (Whitney and Blake: 26, I 339-1344) little more need be noted here; see, however, bibliographies at end of this article. Duclaux, in a series of articles in the Comptes rendus, has endeavored to show that coagulation at least in the case of metallic hydroxides is due, in great part, to actual change in chemical constitution or composition. His work is collected in a thesis of II 2 pages, presented to the Faculty of Science of Paris. (Abstract in Phys. chem. Centrbl., I, 727). Ramsden (Dubois-Raymonds Archiz., I904, p. 5 I 7 ; Proc. Roy. Soc. (London), 72, i 56-164; Ztschr. phys. Chem., 47, 336-346) has studied the surface structure of colloidal solutions and pointed out the coagulating effect of shaking. $\mathrm{He}$ finds a surface film of higher concentration in all the colloidal solutions studied. Schutt (Ann. Phys. (4), 13, iI 2-746), working principally on glycerol and soap solutions, rejects the explanation of a surface laver of greater viscosity and treats the liquid as a heterogeneous system. Bütschli (Ber. d. k.bayr. Akad. Wiss., 33, 215-230, 1903) finds that solutions of dextrin and gums in 65 to 70 per cent. alcohol on drying show cellular structure and urges this as evidence that the liquids really consist of two phases. The most striking departure in the study of colloids is perhaps the use to which some optical methods have of late been put. Lobry de Bruyn and Wolff under the title "Can the molecules in solution be demonstrated by the optical method of Tyndall"? (Versl. k. Ac. Wet. Amsterdam, 12, 778788; Rec. Trav. Chim. 23, I 55) point out that the diameter of particles of colloidal suspensions or solutions, as usually calculated, are only some tenfold greater than the commonly accepted figures for chemical molecules (Cf. Lobry de Bruyn. Rec. Trav. Chim., I9, $25 \mathrm{I}$ ). They then apply a beam of light filtered through picric acid (to avoid danger of fluorescence) to solutions of inorganic salts, alcohol, acetamide, etc., but observe no reflections. In the case of various sugars in aqueous solution and benzoic esters of mannite and other poly-acid alcohols in organic solvents they obtain reflections and believe the question can be answered in the affirmative. A somewhat similar paper by Rachlmann (Berl. Klin. Wochensch., No. 8, 186-190, 1904; abstract in Phys. chem. Centrbl., I, 426) states that with the Siedentopf and Zsigmondy microscope (Ann. Phys., (4), Io, I-39), he was able to watch the breaking-up of glycogen aggregates by diastase solution. $\mathrm{He}$ also mentions seeing some submicroscopic bacteria feeding on molecular complexes of albumin solutions. How much allowance must be made in these cases for subjective influences the reviewer hesitates to say. Bredig and Weinmayer 
(Boltzmann Festschrift, 839-847) have measured the total surface of colloidal particles of gold in solution by amalgamating them through the addition of alkaline mercuric chloride solution and then measuring the rate of catalysis of hydroperoxide. The latter has been shown to be directly proportional to the surface of mercury exposed. Further, from the known amount of mercury added, the thickness of the film may be computed. The minimum amount of mercuric chloride which produced the full effect corresponds to a film $3 \times 10^{-8}$, which agrees well with our accepted order of molecular dimensions.

The applications of physical chemistry to biology in the past two years make quite a chapter in themselves. In fact, the biologists are often more sanguine and enthusiastic in the application of physico-chemical principles than the physical chemists themselves. All that can be attempted here is to note a few representative articles as indications of how physico-chemical ideas are making themselves felt in biology. The particular branch which of late has perhaps attracted most attention is that of toxins and antitoxins. Arrhenius and Madsen (Ztschr. phys. Chem., 44, 7-62, 1903; and Centrbl. f. Bakt., I Abt., 34, 630-64I, I903) pointed out that certain, at least, of the antitoxins-particularly that of tetanus-accomplished their results by directly uniting with their corresponding toxins to form easily dissociable compounds which are subject, as far as their dissociation is concerned, to the ordinary mass law. This furnishes an explanation of the fact that the first small addition of antitoxin depresses the poisonous effect of the toxin far more than equal succeeding additions. This fact had previously led Ehrlich to assume (particularly for diphtheria) a complex nature for toxins such that one after another of the various bodies, of which he supposed them to be composed, were neutralized by the antitoxin, the first to be neutralized being the most virulent. When Madsen and Arrhenius extended their investigations to the diphtheria toxin and showed that the mass law was capable of explaining all the results obtained by Ehrlich, the latter combated their views vigorously and interested a number of other physiologists, as well as physical chemists, in the controversy. A number of the more important articles on the matter by Ehrlich, von Dungern, Sacks, Keys, Morgenroth, Nernst, Arrhenius, Masden, Walburnand and Koeppe are collected and reviewed by Aron (Phys. chem. Centrbl., $I, 487-492$ ), and a very fair idea of the details of the situation can there be had. Arrhenius and Masden seem to have pretty well made good their original stand. Perhaps the most striking proof of their theory, as far as regards the dissociation of the compound of toxin with antitoxin, lies in an experiment in which, out of an inert mixture of toxin and antitoxin, by simple diffusion (in gelatin), the free and virulent toxin was obtained owing to its rate of diffusion being greater than that of the antitoxin 
and of the compound of the two. The applications of gas-cell measurements to blood by Höber (Pflug. Archiv., 81, 522, and 99, 572-593), Fränkel (Ibid., 96, 60I), and Farkas (Ibid, 98, 551576) have led, after some controversy, to agreement on its complete neutrality. Höber's first measurements were vitiated by the currents of hydrogen, used to saturate the electrodes, removing carbon dioxide and thus producing artificially an alkaline reaction. In his last set an amount of carbon dioxide, corresponding to its partial pressure over the normal blood, was added to the hydrogen from the start. Farkas worked with closed electrodes, and Fränkel with palladium electrodes, previously saturated with hydrogen by electrolysis. Friedenthal (Ztschr. allgem. Physiol., 4, 43-6I) has applied his indicator-methods (see below) to various body fluids, finding them nearly all neutral. The equilibrium between oxygen and haemoglobin still continues to occupy several workers; see Loewy (Archiv. Anat. $u$. Physiol., 1904, pp. 166 and 231), and Bohr (Centrbl. Physiol., 13, 7 × $3^{-}$ 7 I 5 , and $17,682-688$ ). In the matter of electro-physiology, electromotive force produced by diffusion through a semipermeable wall (see Ostwald, Ztschr. phys. Chem., 6, 71, I890) is beginning to attract more attention. Brünnings (Pflug. Archiv., I00, 367-427) points out that though the ordinary fluid concentration cells are capable of producing only a very slight electromotive force when a diaphragm is introduced which is only permeable to one of the ions of a compound, very small differences of concentration are able to produce quite appreciable effects and that in the organism many such combinations may be arranged in series as it were. Höber (Pfiug. Archiv., Ior, 607-663, and ro2, 196-205) makes use of somewhat similar conceptions, together with the phenomenon of electrical endosmose to explain the passages of body fluids through a membrane, apparently against the osmotic pressure.

Three very welcome papers on the absolute value of the "endpoint" with various indicators, have appeared by Friedenthal, Salessky and Fels (Ztschr. Elektroch., ro, I33-II9 and 204-2I4). The first two workers employed gas cell methods to determine the concentration of $\mathrm{H}$ and $\mathrm{OH}$ ions, while Fels checked these results by an application of the mass law to mixtures of salts with weak acids and bases. The measurements on the whole agree fairly well with one another, though the authors take issue on some points as, for example, the effect of concentration of the indicator itself. Friedenthal's work covers not only the region immediately about the neutral point, but supplies a list of indicators with end-points all the way from twice-normal acid to twice-normal alkali. The discussion of, and the practical suggestions upon, the methods of preparing standard solutions of very slight acidity and alkalinity are particularly interesting and suggestive. Vaillent (Compt. rend., 137, 849-85I, 1903) has 
measured the electrical conductivity and the spectral absorption of methyl orange solutions, and finds their relation not in harmony with either Ostwald's theory of colored ions or that of Küster (Ztschr. anorg. Chem., I3, I27-I 50, I897). He explains the changes on the ground of a molecular rearrangement in presence of acid (see Steiglitz, this Journal, 25, I I I 2-I I 27).

Out of the great mass of reaction velocity determinations now appearing may be mentioned here a dynamic study of the Friedel and Crafts' reaction by Steele ( $J$. Chem. Soc., 83, I470-I480). Cases are pointed out where the reaction appears as monomolecular and others of the bimolecular type and inferences drawn concerning the intermediate compounds. Slator (Ztschr. phys. Chem., $\left.45,5^{1} 3-536\right)$ has made a systematic study of the rate of chlorination of benzene in the light and in presence of various catalyzers. In every case in the dark the viscosity was directly proportional to the concentration of the chlorine. In the light, however, it was proportional to the square of the chlorine cone $(C f$. here Bodenstein, Ztschr. phys. Chem., 22, 23, I897). Stannic chloride and ferric chloride accelerated in proportion to their concentrations. With iodine monochloride the velocity was proportional to the square of its concentration. Quartoroli ( $\mathrm{Gaz}$. chim. Ital., 34, 505-516; Phys. chem. Centrbl., I, 564) finds the temperature coefficient for saponification of methyl and ethyl acetate to vary abnormally near the temperature of maximum density of water and the irregularity to follow this point, as the latter is depressed by addition of alcohol. A series of five articles, by Lobry de Bruyn, Steger and Tijmstra (Ztschr. phys. Chem, 49, 329-367), deals with the alcoholates as regards their reaction velocity with other bodies and their electrical conductivities. Reactions of the type $\mathrm{RI}+\mathrm{NaOR}_{1}$ appear to be ion reactions. Those of the type $\mathrm{C}_{6} \mathrm{H}_{4}\left(\mathrm{NO}_{2}\right)_{2}+\mathrm{NaOR}$ to be more complicated in mechanism. Incidentally, the rather surprising fact is brought out that in distributing itself between water and alcohol, even in weak alcohol, the greater part of the sodium is probably there as alcoholate.

The study of reaction velocity in heterogeneous systems has received considerable impetus from a paper by Nernst ( $Z$ tschr. phys. Chem., 47, 52-55), pointing out how the phenomena as a whole must be resolved into ( 1 ) diffusion to and from the surface of discontinuity, and (2) the real reaction velocity in the homogeneous phases. Following this paper is one by Brunner (Ibid., 56, I03), working in Nernst's laboratory, on the rate of solution of various solids and the electrolytic reduction of iodine. In this the above theory is applied to practical cases with satisfactory results. Haber (Ztschr. Elektroch., Io, I 56-157) points out the application of the above to his former work on rate of attack of glass surfaces by water and concludes that much of the reaction observed by him took place within the glass as solid solution or viscous liquid. Hantzsch (Ztschr. phys. Chem., 48, 289-329) 
treats of the reaction of ammonia gas on the solid organic acids from the same standpoint. Hertzog (Ztschr. physiol. Chem., 4I, $4^{16-424)}$, considering enzymes as constituting a second phase in the solutions to which they are added, treats the whole problem of enzyme reactions in the light of the above and sees in it an explanation for the predominance of the monomolecular type. Schurr (J. Chim. Phys., 2, 245-306) has treated the rate of solution of salts in their own and other solutions from another standpoint, but as he employed no stirring whatever it is hard to compare his results directly with those of the other workers.

The first well-defined reaction in a homogeneous solid $(i . e$, crystalline system) has lately been given us by Ciamician and Silber (Ber. chem. Ges., 34, 2040-2046, I9OI) in the passage of $o$-nitrobenzaldehyde into $o$-nitrosobenzoic acid, which takes place without disturbing the crystal form in the process. The work has been confirmed by Lobry de Bruyn and Jungius (Rec. Truv. Chim., 22, 298, 1903). Starting from this suggestion, Bruni and Callegari (R. Acc. d.Linc., I3 (5), 567-573; see Phys. chem. Centrbl., $I, 448$ ) have studied a large number of nitro and nitroso derivatives of aromatic bodies by the crysocopic method and found the formation of mixed crystals between them a very general phenomenon. In this connection may be mentioned an article by Sachs and Hilpert (Ber. chem. Ges., 37, 3425-343I, 1904), pointing out that the above photochemical reaction is characteristic for $o$-nitro compounds.

Vondráček (Ztschr. anorg. Chem., 39, 24-40) finds that if platinum occludes oxygen it oxidizes hydrogen in both ammonium salts and ammonia. If the platinum is free from oxygen it reduces nitrous acid. The author believes this typical for other cases of platinum catalysis.

Luther and Schillow (Ztschr. phys. Chem., 46, 777-817) have given a comprehensive treatment of induced reactions. Such systems may be illustrated by the oxidation of arsenious oxide ("acceptor") by hypobromous acid ("actor") which does not take place by itself, but does take place if sulphurous acid ("inductor") is being oxidized at the same time. This case is explained by intermediate formation of bromous acid, which oxidizes arsenious oxide directly. In the paper it is pointed out how common this type of reaction is and how, by suitable velocity measurements, the mechanism and the intermediate products may be determined.

In the field of equilibrium in heterogeneous systems the work on alloys has, perhaps, been attracting most attention, but the greater part of it consists of accumulation of data for individual systems and cannot be here reviewed to advantage. The amount of data in this field is fast getting to the point where something analogous to the Beilstein in organic chemistry is a necessity. A rather new departure in the experimental side 
of the work is the study of the distillation of alloys by Moissan and O'Farally (Compt. rend., I38, I659-I664). Copper and lead form two immiscible layers. Lead and tin give a system comparable with alcohol and water, and copper and tin give one comparable with formic acid and water, having a maximum boiling-point. The first volume of the collected work on the Stassfurt salts, which has occupied van't Hoff and his students for some years, has lately appeared. It contains the data for the simpler systems already published in the Sitzungsbericht of the Prussian Academy. The work on calcium sulphite in its various forms was summarized in a single article some time ago ( $Z$ tschr. phys. Chem., 45, 257-306). In this connection see also Rohland (Ztschr. anorg. Chem., 36, 332-339) concerning the setting of plaster of Paris and the catalysis of the same. Wittorf (Ztschr. anorg. Chem., 39, I87-I96) has studied the equilibrium of silicon dioxide in fusion of alkaline carbonates at $780^{\circ}$ and $825^{\circ} \mathrm{C}$, and finds the dissociation pressures for the carbon dioxide to decrease in the order $\mathrm{Li}, \mathrm{Na}, \mathrm{K}, \mathrm{Rb}$, Cs. Smith (Ztschr. anorg. Chem., 37, 332-336) has made a corresponding study in potassium and sodium carbonates with $\mathrm{SiO}_{2}, \mathrm{TiO}_{2}, \mathrm{ZrO}_{2}$ and $\mathrm{ThO}_{2}$ as solid phase, and finds at $900^{\circ}$ and atmospheric pressure for carbon dioxide, the degree of combination falls off in the order above given. Tammann (Ztschr. anorg. Chem., 37, 448-454) shows that the inversion point from $\alpha$ to $\beta$ iron (at $770^{\circ}$ ) is not affected by pressure, while that from $\alpha$ to $\gamma\left(\right.$ at $890^{\circ}$ ) is lowered $0.0029^{\circ}$ for every $\frac{\mathrm{Kilo}}{\mathrm{cm}^{2}}$ and at $12,000 \frac{\mathrm{Kilo}}{\mathrm{cm}^{2}}$ the $\alpha$ - $\beta$ - and $\gamma$-forms may be in equilibrium together. At $1 /$ roo of the earth's radius below the surface the pressure is 6,000 atmospheres, corresponding to a magnetic inversion at $600^{\circ}$ and the interior of the earth cannot, therefore, be magnetic as far as iron is concerned. In the mutual solubilities of liquid phases Hudson (Ztschr. phys. Chem., 47, I $13-$ I 5 ) has given us a new and interesting case in nicotine and water. At room temperature they are miscible in all proportions, at $60^{\circ}$ they separate into two layers, at $90^{\circ}$ what was at first the lighter layer becomes the heavier and sinks to the bottom, and at $210^{\circ}$ they are again miscible in all proportions. In the determination of the solubility of slightly soluble substances Böttger ( $Z$ tschr. phys. Chem., 46, 52I-6Ig) has given us much new data from conductivity measurements and a critical discussion of the errors of the method. The substances, some thirty in all, are silver, lead and calcium salts. Starting from the work of Richards (this Journal, 23, R. I 59, and 24, R. 44I) on change of heat capacity during reaction, van't Hoff (Boltzmann Festschrift, pp. 233-24I) has treated the particular case of melting and transition points, showing that by taking account of this factor we may explain the apparent exceptions (see Bodlander, Ztschr. Elektroch., 8, 835 , 1902) to the rule that endothermic reactions become nore 
complete as the temperature rises and vice versa. A very satisfactory review of the whole subject is to be found in Ztschr. Elektroch., 10, 633-642, I904.

In structural chemistry Elbs (Ztschr. Elektroch., 10, 579$5^{83}$ ) has shown that we may have structural obstacles to electrolytic reductions just as we have in purely chemical reactions. Wedekind (Ztschr. phys. Chem., 45, 235-248) has given a general view of the optical activity of pentavalent nitrogen. A similar review of the work up to date and some new data on compounds of the type of $N R_{2} R^{\prime} R^{\prime \prime} R^{\prime \prime}$ is given by Aschan (Ztschr. phys. Chem., 46, 293-322). Mohr (Ber. chem. Ges., 37, 2702-2704) points out an interesting case whereby a reaction of the type

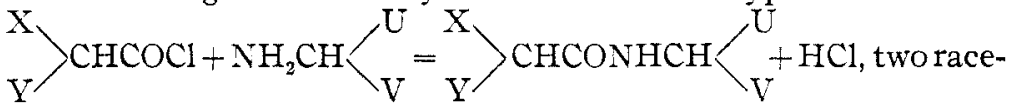

mic compounds are formed which may be separated by the ordinary methods without the help of optically active acids and bases and thus the activity of the fundamental compounds indicated without actually separating them as such.

It is gratifying to notice how the geologists and metallurgists are beginning to apply phase rule methods to the problems of fusion and solidification of rocks and slags. For a summary and discussion of some of this work see Vogt (Vidensk.-Selsk. Skrifter, No. 8, I903) who has also published a separate book (see list below) and Jüptrier (Tscherm. min. u. pet. Mitt,, 23, I80-214, 1904). An attempt to work out a general rock classification on this basis has been made by Osann (Ibid., I9, 35I ; 20, 399-558; 21, 365$448 ; 22,323-356)$, but as yet it is more suggestive than practical.

The effect of centrifugal force on equilibrium in solution has been investigated by van Calcar and Lobry de Bruyn (Versl. $k$. Acad. v. Wet. Amsterdam, I2, I903, (4), 936-940; Rec. Trav. Chim., 23, 218; Phys. chem. Centrbl., I, 518). With a centrifugal force equal to 400 times gravity they succeeded in causing considerable crystallization from solutions of $\mathrm{Na}_{2} \mathrm{SO}_{4}, \mathrm{KCNS}, \mathrm{K}_{4} \mathrm{FeCN}_{\theta}$, $\mathrm{KI}$ and sugar. The magnitude of the effect reported is surprisingly great. Further work is promised.

The problems connected with ozone seem to have attracted special interest of late. The most striking departure is perhaps the theory-which has gained pretty general acceptance-that the formation of ozone by the brush or the silent discharge, as in most of our practical ozonizers, is due not to any direct electrical action on the oxygen itself, but is simply a photochemical effect, due to the very high ultraviolet light accompanying such discharges. The best proof of this lies in the fact that a vacuum tube or a mercury arc lamp, made of pure quartz when lighted up by the discharge, produces powerful ozonization in the surrounding air. The transparency of quartz to these rays is, of 
course, well known. Goldstein (Ber. chem. Ges., 36, 3042-3046) found that a Geisler tube of oxygen under a few centimeters pressure immersed in liquid air, when excited, condensed ozone on its inner walls in blue drops, the pressure falling to a small fraction of a millimeter. If oxygen were steadily admitted to maintain the original pressure, a continuous formation of liquid ozone could be maintained. Clement (Ann. Phys. (4), 14, 344-353) attempted to prepare ozone by passing oxygen through a hollow Nernst lamp filament (temperature $2200^{\circ}$ ) and quickly chilling it on emerging, but he obtained negative results and shows by calculation that, even if any were formed at this temperature, it would be highly improbable that we could cool it quickly enough to prevent its complete decomposition. The electrolytic preparation of ozone, especially the influence of the composition of the electrolyte and the character of the electrodes, has been discussed at length by Gräftenburg (Ztschr. anorg. Chem., 36, 355-379) and Kremann (Ibid., 36, 403-4II.) Schenk and Richarz (Sitzungsbr. Preuss. Akad., I904, pp. 37-45 and 490-493; Phys. chem. Centrbl., I, 690 and 707) point out the similarity between ozone and the emanations from radioactive bodies and advance a theory of ozone formation through the agency of gas ions. Part of the luminescence of zinc blend under the influence of radium radiation is attributed to ozone, which, the authors show, has the power of making zinc blend luminous, at the same time oxidizing it to the sulphate. In an atmosphere of carbon dioxide, the screen did not fluoresce so strongly under the radium rays. Schenk and Mihr (Ber. chem. Ges., 37, 3464-3467) have continued this work.

Appended is a list of publications of physico-chemical interest which have appeared during the period covered by the above review.

\section{BIBLIOGRAPHIES.}

Bibliographie der Metalllegierungen.-M. Sack, Ztschr. anorg. Chem., 35, 249-328; also as pamphlet, Leop. Voss Hamburg and Leipzig, I903, 2 Marks. Contains 880 references.

Ueber organische Losungs- and Ionisierungsmittel.-P. Walden, Ztschr. phys. Chem., 46, 103-1 88 .

Conductibilité, dissociation et propriétés des electrolytes dans les dissolvants autres que l'eau.-P. Dutoit, $J$. Chim. Phys., I, 617-657 (I904). General review of subject and an extensive bibliography up to September, 1903.

Neuere Arbeiten über Funkenspektra, I and II.-Ztschr. wiss. Photog., I, 237-245 and 289-304 (1903). A critical review and bibliography of the subject.

The Electric Furnace, Its Origin, Transformations and Applications; Part I.-The Electrochemist, 3, 88-100 (1904). A bibliography is appended.

Bibliographie der seltenen Erden.-R. J. Meyer, Ztschr.anorg. Chem., 43, 416-492 (1905), contains 777 references. 


\section{Books of Physico-Chemical Interest.}

(a) ORIGINALS.

ABEL, E.--Theorie der Hypochlorite, Eine physikalisch chemische Studien. Fr. Deuticke Leipzig und Wien, 1904, 6I pp. 2 Marks.

Bischoff, C. A.-Materialien der Stereochemie in form von Jahresberichten bearbeitet, $\mathrm{Bd}$. I, I 894 - I898 ( I $36+840$ pp.); Bd. II, r899-I902 ( I 37 pp.); Vieweg \& Sohn, Braunschweig, r904. 9o Marks. These form a continuation of Bischoff and Walden's "Handbuch der Stereochemie."

BoltzManN, L.-Festschrift gewidinet zu 60 geburtstag; $12+930$ pp., Ior Figs., 2 Plates. J. A. Barth, Leipzig, I904. I 8 Marks. Contains II7 articles by his associates and former students.

BENEDICTS, C.-Recherches physiques et physico-chimiques sur l'acier au carbone (Doctor's Thesis, Upsala, I904) $9+2$ I 9 pp., 4I Figs., 28 Micrographs. Libr. d. Université. C. J. Lumstrom (also A. Felix, Leipzig. to Marks). Review by author Phys, chem. Centrbl, I, 470.

ENGLER, C., and J. WeISSBERG-Kritische Studien über die vorgange der Autoxydation, II +204 pp. Viewig \& Sohn, Braunschweig, I904. 6 Marks.

Findilay, A. See under Ramsay.

Getman, F. H. Iaboratory Exercises in Physical Chemistry. $8+24$ I pp. Wiley \& Sons, New York, 1904. \$2.00.

HAMBlRger, H. J.-Osmotischer Druck und Ionenlehre in dem Medicinischen Wissenschaften, Zugleich Lehrbuch physikalisch Chemischer Methoden. J. F. Bergmann, Wiesbaden. Bd. I, Physikalisch chemische Grundlagen und Methoden. Die Beziehungen zur Physiologie und Pathologie des Blutes. 539 pp., 23 Figs, 1902. I6 Marks. Bd. II, Circulirendes Blut. Lymphbildung Hydrops. Resorption. Harn und Soristige Secrete. Elektrochemische Aciditatsbestimmung Reactions-Verlauf. 516 pp., 28 Figs., 2 Plates. Igo4. I6 Marks.

HöBER, R. Physikalische Chemie der Zelle und Gewebe. 334 pp., 2 I Figs. Wm. Engelmann, Leipzig, 1902. Io Marks.

Julien, H. F., and E. SMart. Cyaniding Gold and Silver Ores. $450 \mathrm{pp}$. Griffin \& Co., London, I904. 2is. net.

JüPTNER, H. v. Lehrbuch der physikalischen Chemie für technische chemiker und zum Gebrauche an technischen Hochschulen und Bergakademien. F. Deuticke, Leipzig and Wien. I Teil, Materie und Energie, I94 pp. I904. 4 Marks. II Teil, Chemisches Gleichgewicht und Reaktionsgeschwindigkeit. Erste Hefte Homogene Systeme. I62 pp. I904. 3.50 Marks.

LEHFELDT; R. A.-See under Ramsay.

OPPENHEIMER, C. Toxine and Antitoxine. iv +227 pp. G. Fischer, Jena, I904. 6 Marks (contains bibliography).

OStwald, W., and R. Luther.-Hand- und Hülfsbuch zur Ausführung physiko-chemischer Messungen. 2 Auf. I $2+493$ pp., 319 Figs. Engelmann, Leipzig, I902. I 5 Marks.

RAMSAX, SIR WM. An Introduction to the Study of Physical Chemistry. $48 \mathrm{pp}$. Longmans, Green \& Co., Iondon. is. Forms introduction to series 
of text-books on Physical Chemistry, edited by Ramsay and is included in the first volume of the series. The series is to include the following: The Phase Rule and Its Applications, A. Findray. 203 pp., 53 Figs. \$1.60. Stoichiometry, S. Young. In preparation. The Relation between Chemical Constitution and Physical Properties, S. SMILES. In preparation. Electro-Chemistry, R. A. I.EHFELDT and T. G. MOORE, of which one volume is already out. $8+268$ pp. \$r.6o. Spectroscopy, E. C. C. Baly. In preparation. Thermodynamies, F. G. Donnas. In preparation. Chemical Statics and Dynamics, J. W. MELLOR. \$2,00.

RighI, A. Das Radium. 68 pp., I6 Figs. Bologna, Nicola Zanichelli, I904. $3 \mathrm{fr}$. (contains descriptions of much new apparatus).

Rohland, P. Der Portland Zement vom physikalisch chemischen Standpunkt. iv $+98 \mathrm{pp}$. Quandt \& Handel, Leipzig, 1903. 2.80 Marks.

ROHLAND, P. Der Stuck und Estrichgips physikal chemisch Untersuchungen. $74 \mathrm{pp}$. Quandt \& Handel, Leipzig, I904. 3 Marks.

Roоzевоом, H. W. B. Die heterogenen Gleichgewichte vom Standpunkt der Phasenlehre. Vieweg \& Sohn, Braunschweig. Heft I, Die Phasenlehre; Systeme aus Einer Komponente. $9+22$ I pp., 54 Figs. I901. 5.50 Marks. Heft II, Systeme aus zweier Komponenten; I Teil. I $2+467$ pp., I 49 Figs., 2 Tafeln. Ig04. I 2.50 Marks.

Ruhmer, E.-Radium and Andere radioaktive Substanzen. 5 I pp. Verlag. d. Administ, Fachzeitschrift "Der Mechaniker," Berlin, I904. A general review and bibliography. 2.50 Marks.

RUTHERFORD, E. Radio Activity. 399 pp. The University Press, Cambridge, Eng., 1904. 6s. 6d.

Tammann, G.-Kristallisieren und Schmelzen. 348 pp., 88 Figs. J. A. Barth, Leipzig, I903. 9 Marks.

TrauBE, I.-Grundrisse der physikalische, Chemie. $8+360$ pp., 24 Figs. F. Enke, Stuttgart, I904. 9 Marks.

VoGT, J. H. L.-Die Silikatschmelzlosungen, Bd. I, Uber Mineralbildung in Silikat Schmelzlosungen. 5+16I pp., 26 Figs. J. Dybwad, Christiania, I903. 5 Marks. A second volume on melting-points is in progress.

Walden, P.-Wilhelm Ostwald. I20 pp. Helogr. Portrait. Wm. Engelmann, Leipzig, I904. 4 Marks.

WEDEKIND. E.-Stereochemie (Samlung Goschen, Bd. 201). Io6 pp., 34 Figs. Goschen, Leipzig, I 904. 0.80 Mark.

Young, S.-Fractional Distillation, 284 pp., 72 Figs. Macmillan \& Co., London, 1903. 8s. 6d.

\section{(b) TRANSLATIONS}

CoHEN, E. (transl. M. H. FIshER).-Physical Chemistry for Physicians and Biologists. 343 pp. Henry Holt \& Co., N. Y., 1903. \$1.75.

CURIE, MME. S. (transl. W. KaUfMaNN).-Untersuchungen über die radioaktiven Substanzen. I23 pp. Vieweg \& Sohn, I904. 3 Marks (first volume of set of monographs).

van Deventer, C. M. (transl. B. B. Boltwood).-Physical Chemistry for beginners; with an introduction by J. H. van't Hoff. $157 \mathrm{pp}$. Wiley and Soris, N. Y., I904. \$1.50. 
DOLEZALEK, F. (transl. C. L. voN ENDE),--The Theory of the Lead Accumulator (Storage battery). I +241 pp., 3 Figs. Wiley \& Sons, N. Y., I904. Cloth $\$ 2.50$.

DUhem, P. (transl. G. K. Burgess).-Thermodynamics and Chemistry. A Non-mathematical Treatise for Chemists and Students of Chemistry. 445 pp. Wiley \& Sons, N. X., 1903. \$4.00.

VAN'T HoFf, J. H. (transl. A. SMITH).-Physical Chemistry in the Service of the Sciences. Decenial Publications of University of Chicago. Series 2, volume XVIII. I23 pp. The University of Chicago Press, I903. \$1.50.

Mendeléff, D. (trans. G. KAMENSky).-An Attempt toward a Chemical Conception of Ether. 51 pp. Longmans, Green \& Co., London, I9o4. 2s. net

Molssan, H. (transl. V. LenHeR). - The Electric Furnace. The Chemical Publishing Co., Easton, Pa., 1904. \$2.50. A second translation by A. F. de Mouilpied has been published by Longmans, Green \& Co.

NeRnst, W. (trans1. C. S. PALMER and R. A. LEHFELDT).-Theoretical Chemistry. Second English from fourth German edition. 77 I pp. Macmillan \& Co. \$3.75.

\section{RECENTLY ESTABLISHED JOURNALS.}

Electrochemical and Metallurgical Industry (first two volumes "Electro Chemical Industry").-Edited by E. F. Roeber, began Jan., I 903 ; I 2 numbers a year (I vol.). The Electrochemical Publishing Co., N. Y. \$2.00 per year.

Journal de Chimie Physique.-Edited by P. A. Guye, began 1903; 8 to ro numbers form yearly volume of 600 to $700 \mathrm{pp}$. Gauthier Villars, Paris. 25 Francs per volume.

Physikalisch chemisches Centralblatt. Edited by Max Rudolphi in Darmstadt. Began with year I904. 24 numbers form yearly volume. Vol. I, 808 pp. Reviews are printed in German, English or French. Gebr. Borntraeger, Leipzig. 3o Marks per year.

Zeitschrift für wissenschaftlicher Photographie, Photophysik und Photochemie.-Edited by H. Kayser, E. English and K. Schaum. Began March, 1903. I 2 numbers a year ( 1 vol.). J. A. Barth, Leipzig. 20 Marks per year.

\section{NEW BOOKS.}

Ei.ectric Furnaces aNd Their Industrial, Applications. By J. WrIGHT. New York: The Norman W. Henley Publishing Co., 132 Nassau Street. Price, \$3.00.

In fourteen sections, as they are called, covering 283 pages, the author presents most interesting and very instructive data in regard to electric furnaces. In the first three sections the various kinds of furnaces are presented, accompanied by historical and general statements of value. Thus mention is made that "the 